\title{
The effects of spiritual experience and church commitment among South Korean young adult immigrants in the United States: a mixed-methods study
}

\author{
Chulwoo Park ${ }^{1} \mathbb{0}$, Mark Edberg ${ }^{2}$ \\ 1 Department of Public Health and Recreation, San José State University, San José, California, United States, ${ }^{2}$ Department of Prevention and \\ Community Health, The George Washington University Milken Institute School of Public Health, Washington D.C., United States \\ Keywords: immigrants, south korea, religion, spirituality
}

https://doi.org/10.29392/001c.17608

\section{Journal of Global Health Reports}

Vol. 4, 2020

\begin{abstract}
Background
Korean American immigrants have become one of the largest Asian American ethnic group in the United States, and Christianity have been preserving their ethnic identities. However, little is known if church commitment is associated with developing emotional well-being and work capacity. The study aims to understand the attachment to church and its effect on level of emotional well-being and work (or school) performance among South Korean young adult immigrants who have a strong faith in Christianity.
\end{abstract}

\section{Methods}

A sequential, mixed-methods study examined two dimensions of church attachment, level of religious belief and involvement in church activities. A total of 23 participants was initially recruited through purposive and snowball sampling, and then 22 of them were divided into two high-belief groups-high-active church members and low-active church members - for further analysis. A screening questionnaire, a quantitative component, was used to exclude a low-level believer. Consecutively, an in-depth interview, a qualitative component, was conducted to further investigate the emotional well-being and work (or school) performance.

\section{Results}

Although a small sample was collected, it generated initial insights into the effects of time commitment for church among immigrants. Regardless of leadership roles and level of activity at church, strong beliefs appeared to improve emotional well-being and support motivation to improve the performance of major activity of daily living.

\section{Conclusions}

The major significance was to support further research on religious belief and practice and its potential association with emotional well-being and social adjustment for Koreans, as well as other immigrants. The study applied a culturally specific lens to focus on a particular minority immigrant population.

Since the passage of the Immigration Reform Act in 1965, Korean American immigrants have become the fifth-largest Asian American ethnic group in the U.S., totaling 1,706,822 in 2012. ${ }^{1-3}$ Among international students in the U.S., the South Korean student group is the third largest, with over 63,000 students, or 6.5 percent of total foreign student enrollment in $2016 .{ }^{4}$ Reports show that these immigrants often suffer from acculturative stress due to cultural gaps between South Korea (hereafter, Korea) and the U.S. ${ }^{5}$ Furthermore, this acculturative stress is a strong predictor of mental-health symptoms. To overcome the difficulties of living in a foreign country, Korean immigrants and international students tend to establish strong social bonds with each other by attending Korean church services and activities.
Cadge and Ecklund (2007) stated that "religious identities become more salient for immigrants in the United States than in their nations of origin because of the role religions have in preserving ethnic identities." 6 In addition, ethnic church can help immigrants establish a sense of belonging, identity, value, and community in the new environment. ${ }^{7}$ Korean Protestant churches have been creating and preserving Korean spaces in major U.S. cities for Korean immigrants to provide a cultural, religious, and ethnic sense of home. ${ }^{8,9}$ Furthermore, Korean Protestant churches bring individuals together, help immigrants maintain their cultural traditions, provide social services, and satisfy the needs for social status, prestige, and recognition within the immigrant community. ${ }^{10}$ Although it has been reported 
that daily spiritual experiences and social support are inversely associated with depression among elderly Korean immigrants, ${ }^{2,11}$ only a few papers touched upon whether this association also holds among Korean young adults in the U.S. ${ }^{12}$ In general, "religious/spiritual beliefs and practices" are associated with improving both mental and physical health. ${ }^{13,14}$ However, Korean church members have been forced by pastors to focus on evangelism and training, rather than the spiritual growth and disciple-making, ${ }^{15}$ and still little is known whether church commitment is linked to the development of emotional well-being and work capacity.

\section{STUDY OBJECTIVES AND RESEARCH QUESTIONS}

The purpose of this research was to conduct a sequential, mixed methods study that included a screening questionnaire for assessing level of religious belief and involvement in church activities (quantitative) followed by in-depth qualitative interviews about the relationship between church attachment and emotional well-being as well as work performance (qualitative), in order to obtain preliminary findings and generate insights regarding future research. The research was guided by two key research questions: 1) Do young Korean immigrants with a high level of religious belief (but low involvement in church activities) have a similar level of emotional well-being and work performance compared to individuals who are actively involved in church activities? and 2) What factors could link a person's level of participation in church activities to emotional well-being as well as work (or school) performance? Schutte et al. ${ }^{16}$ defined individuals' emotional well-being with two important aspects: positive mood and high self-esteem. Positive mood, supporting approach behavior, is from feelings of enthusiasm and alertness. ${ }^{17-19}$ In addition, the level of self-esteem, perception of value or self-worth, is from the outcome of self-evaluation. ${ }^{20-23}$ The definition of emotional well-being in our context is "the state of healthy coping, feeling happy, and a high level of work (or school) performance.” A suggestive relationship between religion and emotional well-being is demonstrated in Figure 1.

\section{METHODS}

\section{STUDY DESIGN}

Strong believers normally choose to express their belief and reliance upon God between two different ways: 1) voluntarily devoting themselves to the mission and ministry of the church as a church leader, or 2) carrying out their Christian ministry at workplace or school, rather than at church. A rationale for this study was only to include strong believers as a study participant to understand whether the intense involvement in church activities would actually help them to improve emotional well-being and work (or school) performance outside the church, by comparing those two different perspectives of strong believers.

Although the study was based on small sample that may not be generalizable, this preliminary approach enables us to get initial insights into association between the level of church involvement and emotional well-being/ work (or school) performance among high-level believers in Jesus

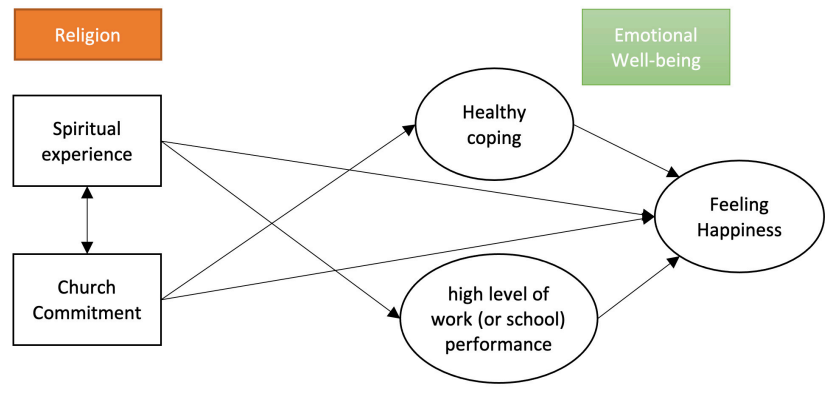

Figure 1. Suggestive relationship between religion and emotional well-being

Christ. To gain preliminary insights-personal background, contexts of involvement in the church, or other factors that might have affected individuals' beliefs in God and participation in church activities-with respect to these research questions, we conducted a sequential, mixed methods study in which a primarily phenomenological qualitative study was supplemented by quantitative screening questionnaire results for identifying subgroups, validation and triangulation (Online Supplementary Document).

\section{INCLUSION AND EXCLUSION CRITERIA}

Basic inclusion criteria for eligibility are listed in Table 1. Tables 2-1, Table 2-2 and Table 2-3 summarize participant subgroups and the criteria for each of their memberships (with inclusion and exclusion criteria). Only high-level believers from Group 1 and Group 2 were included for the analysis because we wanted to see whether the level of church involvement has a strong influence on emotional well-being and work (or school) performance among highlevel believers.

In the context of this study, the term "young adult" as applied to respondents has an important cultural connotation which is not just age-based. "Young adults" refers to those who are unmarried or single, including those who are divorced or widowed. There was one exception among them in terms of category of young adult; one married participant was still included because this person got married just before the date of interview appointment. The age range of participants was 24 and older, with no maximum age as long as they were not yet married. The minimum age was set based on the expectation that most participants had graduated from college, though graduation and a degree were not required. In addition, for this study the term immigrant refers to both the " 1.5 generation" who are foreign-born and immigrated to the U.S. when they were young as well as second generation individuals who are U.S.-born and have foreign-born parents.

\section{RECRUITMENT PROCESS}

Data were collected from a purposive sample of a total of 23 Korean young adult immigrants to investigate their lived experiences with respect to church involvement, belief in God, emotional well-being and work (or school) performance. The sample was entirely from a large Korean Protes- 
Table 1. Common inclusion criteria for all study participants

\begin{tabular}{|c|c|}
\hline Inclusion criteria & Description \\
\hline Ethnicity & South Korean \\
\hline $\begin{array}{l}\text { Legal status in } \\
\text { the U.S. }\end{array}$ & $\begin{array}{l}\text { Criteria include U.S. citizen, permanent resident, working visa holder, or international student (foreign-born or } \\
\text { U.S.-born) }\end{array}$ \\
\hline Age & 24 and older, with no maximum age as long as they are unmarried \\
\hline Marital status & $\begin{array}{l}\text { In principle, participants are an unmarried single, a divorced or widowed person, to officially belong to the } \\
\text { young adult group. However, one participant who just got married and left the group recently during the } \\
\text { interview process was also included in the study because this person was still assumed to share characteristics } \\
\text { of the young adult group. }\end{array}$ \\
\hline Church & K church in Virginia \\
\hline $\begin{array}{l}\text { Membership } \\
\text { status at church }\end{array}$ & A regular member who officially completed the Bible study training for newcomers \\
\hline Church service & Used to attend or attends worship for the young group on Sundays \\
\hline
\end{tabular}

Table 2-1. Participant Subgroups

\begin{tabular}{|c|l|}
\hline $\begin{array}{c}\text { Group 1: } \\
\begin{array}{c}\text { High-active member } \\
\text { (12 participants) }\end{array}\end{array}$ & $\begin{array}{l}\text { Participants \#2, \#3, \#5, \#9, \#10, \#11, \#12, \#13, \#14, \#15, \#16, \#20: Strong believers who are high } \\
\text { participants and typically in leadership positions at K church. They demonstrate their strength of } \\
\text { belief by spending a great deal of time in church activities every week. }\end{array}$ \\
\hline $\begin{array}{c}\text { Group 2: } \\
\text { Inactive/low-active member } \\
\text { (10 participants) }\end{array}$ & $\begin{array}{l}\text { Participants \#1, \#4, \#6, \#7, \#8, \#17, \#18, \#19, \#21, \#22: Strong believers who are not high } \\
\text { participants and are not in leadership roles at K church. They focus more on their livelihood than } \\
\text { on church activities but still maintain a high level of belief in God. }\end{array}$ \\
\hline $\begin{array}{c}\text { Group 3: } \\
\text { (1 participant) }\end{array}$ & $\begin{array}{l}\text { Participant \#23: A low-level believer who attends church for many other reasons, such as hanging } \\
\text { out, killing time, refreshing himself, seeking a future spouse, and avoiding loneliness. }\end{array}$ \\
\hline
\end{tabular}

tant church in Virginia that will hereinafter be referred to as "K church." Regarding the researcher-participant relationship, the lead author, who conducted the interviews, was a member of this church and already familiar with most of participants. The lead author's same cultural background as a 1.5 generation Korean facilitated the process of data collection and analysis. However, the potential for bias is acknowledged, and this was addressed through the use of structured qualitative interview and screening questionnaire applied to all respondents.

After obtaining Institutional Review Board (IRB) approval from the George Washington University, the lead author approached potential young adult participants in-person at $\mathrm{K}$ church on Sundays to disseminate study information and determine willingness to participate in the research study. In addition to the in-person recruiting, recruiting occurred via KakaoTalk [Kakao Corp, South Korea], the most widely used mobile instant messaging application among Koreans. Those who expressed a willingness to participate were then sent a brief explanation of the research and interview dates through KakaoTalk. Note that during the study, KakaoTalk was used only for making announcements and communication, not to gather any participants' personal data other than contact information. The participants' contact data were then retained in the lead author's KakaoTalk account for the duration of the study.

\section{SETTING - INTERVIEW LOCATION}

A permission letter from $\mathrm{K}$ church was also obtained to use its facility for interviews. Although participants who currently attend or occasionally attend $\mathrm{K}$ church were recruited, this did not mean that the interviews needed to be conducted at the church. Participants were given a list of possible interview sites, and they were free to choose where they wanted to meet, such as on the premises of the church (7/ $23,30 \%)$ or in a café $(7 / 23,30 \%)$, a restaurant $(4 / 23,17 \%)$, a participant's home $(2 / 23,9 \%)$, a school conference room $(1 / 23,4 \%)$, a school classroom $(1 / 23,4 \%)$, or a library $(1 / 23$, $4 \%)$. An in-person, one-on-one interview method was chosen for this study because it would maximize rapport and facilitate extended conversation if needed.

\section{ETHICS CONSIDERATIONS}

To assure privacy and confidentiality, the interviews were conducted in different locations where each participant felt comfortable speaking freely. The process began by reading out a verbal script of an informed consent form to participants to obtain their verbal consent. Participants were provided study information and resources to contact should they experience any difficulties resulting from participation. The risk of such difficulties, however, was considered to be very low since few questions were asked about the specifics of any emotional well-being issues.

All data were reported anonymously and kept confiden- 
Table 2-2. Inclusion criteria for selecting participants for each group

\begin{tabular}{|c|c|c|c|}
\hline Inclusion criteria & Group 1: High-active member & Group 2: Inactive/low-active member & Group 3: Low-level believer \\
\hline $\begin{array}{l}\text { Duration of } \\
\text { membership }\end{array}$ & $\begin{array}{l}\text { A member of } K \text { church for at } \\
\text { least one year }\end{array}$ & $\begin{array}{l}\text { A member of } K \text { church for at least six } \\
\text { months }\end{array}$ & Same as Group 2 \\
\hline Leadership & $\begin{array}{l}\text { An active member who is } \\
\text { most likely in a leadership } \\
\text { position }\end{array}$ & A member who has no leadership role & \\
\hline $\begin{array}{l}\text { Time and } \\
\text { dedication }\end{array}$ & $\begin{array}{l}\text { A member who attends Friday } \\
\text { and Sunday sermons every } \\
\text { week and organizes or } \\
\text { participates in church events } \\
\text { and gatherings }\end{array}$ & $\begin{array}{l}\text { A member who used to attend or } \\
\text { occasionally attends K church because } \\
\text { of a time conflict on Sundays }\end{array}$ & Same as Group 2 \\
\hline $\begin{array}{l}\text { Strength of } \\
\text { belief } \\
\text { (objectified } \\
\text { through a } \\
\text { screening } \\
\text { questionnaire to } \\
\text { separate groups) }\end{array}$ & $\begin{array}{l}\text { A member who has a high } \\
\text { level of religiosity and } \\
\text { demonstrates a dedication to } \\
\text { his or her duties as a leader }\end{array}$ & $\begin{array}{l}\text { A member who maintains a high level } \\
\text { of belief even if his or her physical } \\
\text { presence in church is infrequent }\end{array}$ & $\begin{array}{l}\text { A member i) who did not } \\
\text { answer "strongly agree" or } \\
\text { "agree" for the question "Do } \\
\text { you believe in the existence } \\
\text { of God?" and ii) who did not } \\
\text { answer "strongly agree" or } \\
\text { "agree" for the question "Do } \\
\text { you believe Jesus died on } \\
\text { the cross for man's sin and } \\
\text { rose from the dead three } \\
\text { days later?" in a screening } \\
\text { questionnaire }\end{array}$ \\
\hline $\begin{array}{l}\text { Attitude } \\
\text { towards work } \\
\text { outside of the } \\
\text { church }\end{array}$ & $\begin{array}{l}\text { A member who does not } \\
\text { necessarily consider their } \\
\text { work performance outside of } \\
\text { the church as a top priority }\end{array}$ & $\begin{array}{l}\text { A member who demonstrates more } \\
\text { dedication to his or her responsibility } \\
\text { at the workplace than at church, while } \\
\text { living with and maintaining a strong } \\
\text { belief in God }\end{array}$ & $\begin{array}{l}\text { A member who } \\
\text { demonstrates more } \\
\text { dedication to his or her } \\
\text { responsibility at the } \\
\text { workplace than at church, } \\
\text { and has weak belief in God }\end{array}$ \\
\hline
\end{tabular}

"Note: In the time and dedication section, Sunday is considered to be the most important day for Christians to attend church mandatorily. For high-active member at K church, it is mandatory to attend church on Fridays as well.

Table 2-3. Exclusion criteria for selecting participants for each group

\begin{tabular}{|l|l|}
\hline Exclusion criteria & Description \\
\hline Ethnicity & Not South Korean \\
\hline Legal status in the U.S. & Illegal status \\
\hline Age & Under 24 years \\
\hline \multirow{2}{*}{ Duration of attending K church } & $\begin{array}{l}\text { For Group 1: Have attended K church for less than one year } \\
\text { For Group 2: Have attended K church for less than six months } \\
\end{array}$ \\
\hline
\end{tabular}

tial. All transcripts included only a number with no personal identifiers. Individual data in the screening questionnaire were used only for eligibility and group selection, and as such were not connected to transcripts by any identifier. They were also maintained separately. Additionally, the audio transcripts were saved in password-protected word files and analytic software. Neither the screening questionnaire, audio interviews, nor transcripts included personal identifiers. These materials were labeled only with a sequential interview number (e.g. interview 1), and applied lock screens and a smartphone password to enhance data security.

\section{SCREENING QUESTIONNAIRE (QUANTITATIVE)}

Aligning with the goal of this study, the purpose of the screening questionnaire before conducting an interview were to confirm whether purposive and snowball sampling was collected correctly, by excluding low-level believers (Group 3) and then dividing participants into two different high-belief groups: high-active members (Group 1) and inactive/low-active members (Group 2) based on their answers for screening questionnaire (Online Supplementary Document).

The theoretical maximum scores of each Likert-type scale for the measurement constructs were indicated in Table 3. Using Likert scales, higher scores indicated greater strength in these categories. To measure belief, participants 
Table 3. Religious strength

\begin{tabular}{|l|c|c|c|}
\hline Measurement constructs & $\begin{array}{c}\text { Overall average scores } \\
(\mathrm{n}=22)\end{array}$ & $\begin{array}{c}\text { Group 1 average scores } \\
(\mathrm{n}=12)\end{array}$ & $\begin{array}{c}\text { Group 2 average scores } \\
(\mathrm{n}=10)\end{array}$ \\
\hline Belief (max: 20$)$ & 16.9 & 17.9 & 15.6 \\
\hline Practice (max: 57) & 36.0 & 43.1 & 27.5 \\
\hline Nine fruits of the Spirit (max: 45) & 31.4 & 31.3 & 31.5 \\
\hline Happiness (max: 174) & 121.9 & 126.5 & 116.3 \\
\hline
\end{tabular}

were asked about adherence to key Protestant Christian beliefs that would be expected of a person of high belief (maximum score: 20): 1) the existence of God; 2) the resurrection of Christ; 3) the importance of the Protestant denomination; and 4) self-evaluation of strength of devotion. To measure practice, participants were asked about 1) the importance of church attendance on Sundays; 2) frequency of studying the Bible and meditating; 3) frequency of praying for others; 4) making offerings; 5) giving money to a religious charity; 6) doing favors for others; 7) leadership experience at $\mathrm{K}$ church in the past or present; 8) the number of hours they engaged in church activities per week; and 9) the number of hours they engaged in church-related activities per week (maximum score: 57). The nine fruits of the Spirit from the Epistle to the Galatians consists of 1) love; 2) joy; 3) peace; 4) patience; 5) kindness; 6) goodness; 7) faithfulness; 8) gentleness; and 9) self-control. To measure this, participants were asked to evaluate the degree to which they experienced each of the nine fruits of the Spirit through a uniform five-point Likert scale (maximum score: 45). Lastly, Hills P and Argyle M's Oxford Happiness Questionnaire was used ${ }^{24}$ to measure the level of happiness of participants (maximum score: 174).

\section{SUBGROUP DETERMINATION (QUANTITATIVE)}

Korean Protestants are highly religious in terms of the frequency of attending church, praying, and reading the Bible. ${ }^{25}$ However, the Korean American Christian churches are loose and inclusive; with people who go to church regularly, some who are deeply religious, and others who do not have a daily spiritual relationship. ${ }^{26}$ In order to investigate study questions, it was necessary to segment participants into subgroups for comparison based on their level of belief and level of church participation.

The sample of 23 was intentionally divided into specific three subgroups, based on a 15-minute screening questionnaire (quantitative component) assessing strength of belief and level of church participation, with high-active believers assigned as Group 1, inactive/low-active members who still have high-level belief assigned as Group 2, and one low-level believer assigned as Group 3. Then, Group 3 was excluded from the analysis.

A participant who answered "undecided," “disagree," or "strongly disagree" for either Question 6. Do you believe in the existence of God? or Question 7. Do you believe Jesus died on the cross for man's sin and rose from the dead three days later? was put into low-level believers (Group 3). Participants who answered "yes" for Question 16-2. Are you currently in leadership position at K church? were assigned to Group 1 and otherwise (answered "no"), were assigned to Group 2. To ensure that inactive/low-active members in Group 2 are also reported high levels of belief, all participants' religious strength was measured in the screening questionnaire using four measurement constructs: belief, practice, nine fruits of the Spirit, and happiness (Table 3).

The refusal rate of those approached to participate was $15.4 \%$ (4/26). Participants were recruited until both Group 1 and 2 had a minimum of 10 participants for comparability, with the final distribution of these two groups at almost equal numbers. Participants were recruited via purposive and snowball sampling. Because belief in this case is related to a Protestant Christian church, criteria for level of belief were based on specific tenets of church belief. 12 participants were placed in Group 1, 10 in Group 2, and just 1 in Group 3.

\section{IN-DEPTH INTERVIEWS (QUALITATIVE)}

Following group selection, all respondents were administered a semi-structured qualitative interview (qualitative component). To minimize risk related to discomfort, general terms were only used such as "emotional well-being" or "undesirable habit" to ask related questions instead of specific terms such as "depression" or "gambling." All interviews were audio recorded. Korean was mainly used but English was also used interchangeably, if necessary. The total duration of interviews including the time for a screening questionnaire ranged from 30 to 101 minutes, with an average time of 61 minutes.

\section{ANALYSIS (QUALITATIVE)}

After interviews were completed, a total of 22 original Korean transcripts (excluding one low-level believer from Group 3) with no personal identifiers as a unit of analysis were entered into a QSR NVivo software file (QSR International, Pty, Ltd) and coded in a two-step process: 1 ) an initial codebook with basic codes derived from the research questions (deductive); and 2) codes that were subsequently added based on new information or categories of information uncovered during analysis of the interview transcripts (inductive). The coded text was then analyzed for common themes within each code and across codes. Important code segments and findings were then translated to English by the lead author for inclusion in this paper. 
Table 4. Sample characteristics

\begin{tabular}{|c|c|c|c|}
\hline Demographics & Overall (except Group 3): $\mathrm{n}_{\mathrm{o}}=22$ & Group 1: $\mathrm{n}_{1}=12$ & Group 2: $\mathrm{n}_{2}=10$ \\
\hline $\begin{array}{l}\text { Age (year) } \\
24-29 \\
30-35 \\
36-41 \\
42-47\end{array}$ & $\begin{array}{c}6(27 \%) \\
8(36 \%) \\
7(32 \%) \\
1(5 \%)\end{array}$ & $\begin{array}{c}3(25 \%) \\
5(42 \%) \\
4(33 \%) \\
0(0 \%)\end{array}$ & $\begin{array}{l}3(30 \%) \\
3(30 \%) \\
3(30 \%) \\
1(10 \%)\end{array}$ \\
\hline $\begin{array}{l}\text { Gender } \\
\text { Male } \\
\text { Female }\end{array}$ & $\begin{array}{l}10(45 \%) \\
12(55 \%)\end{array}$ & $\begin{array}{l}4(33 \%) \\
8(67 \%)\end{array}$ & $\begin{array}{l}6(60 \%) \\
4(40 \%)\end{array}$ \\
\hline $\begin{array}{l}\text { Legal status } \\
\text { U.S. citizen } \\
\text { Permanent resident } \\
\text { Nonresident alien }\end{array}$ & $\begin{array}{c}18(82 \%) \\
2(9 \%) \\
2(9 \%)\end{array}$ & $\begin{array}{c}12(100 \%) \\
0(0 \%) \\
0(0 \%)\end{array}$ & $\begin{array}{l}6(60 \%) \\
2(20 \%) \\
2(20 \%)\end{array}$ \\
\hline $\begin{array}{l}\text { Living arrangement } \\
\text { Alone } \\
\text { With parents } \\
\text { With single parent } \\
\text { With friends } \\
\text { With live-in lover }\end{array}$ & $\begin{array}{c}5(23 \%) \\
12(55 \%) \\
1(5 \%) \\
3(4 \%) \\
1(5 \%)\end{array}$ & $\begin{array}{c}2(17 \%) \\
8(67 \%) \\
0(0 \%) \\
1(8 \%) \\
1(8 \%)\end{array}$ & $\begin{array}{c}3(30 \%) \\
4(40 \%) \\
1(10 \%) \\
2(20 \%) \\
0(0 \%)\end{array}$ \\
\hline $\begin{array}{l}\text { Relationship status } \\
\text { Single } \\
\text { Girlfriend/Boyfriend } \\
\text { Married }\end{array}$ & $\begin{array}{c}18(82 \%) \\
3(14 \%) \\
1(5 \%)\end{array}$ & $\begin{array}{c}10(83 \%) \\
1(9 \%) \\
1(9 \%)\end{array}$ & $\begin{array}{c}8(80 \%) \\
2(20 \%) \\
0(0 \%)\end{array}$ \\
\hline
\end{tabular}

"Note: In the legal status section, the term "alien" describes a person who is neither a permanent resident nor a U.S. citizen. Resident alien and nonresident alien are defined depending on the duration of living in the U.S.: resident alien ( $>5$ years), nonresident alien ( $<5$ years).

\section{RESULTS}

\section{DEMOGRAPHIC INFORMATION (QUANTITATIVE)}

Table 4 includes demographic information about age, gender, legal status, living arrangement, and relationship status collected from screening questionnaire. In general, $82 \%$ $(18 / 22)$ were single, defined as not married or having no girlfriend/boyfriend. There were common characteristics of legal status and living arrangement in Group 1-all (12/12) were citizens of the U.S. and 67\% (8/12) lived with their parents. All of Group 1 participants were 1.5 generation immigrants who came to the U.S. as children or adolescents with their first-generation parents. On the other hand, Group 2 participants were far more diverse with respect to legal status and living arrangements.

For all groups, as a rough proxy measure of emotional well-being, the construct of happiness was highlighted. This was measured using the Oxford Happiness Questionnaire, which consisted of 29 items endorsed on a uniform six-point Likert scale. ${ }^{24}$ The sum of the 29 item scores was the overall measure of happiness.

The screening questionnaire's quantitative results indicate that the average scores for belief and happiness were slightly higher in Group 1, and the average scores for nine fruits of the Spirit was similar between Group 1 and Group 2 (Table 3). This was expected to a certain degree; even though both groups included only strong believers, Group 1 participants were current, active leaders at church who are supposed to demonstrate a deep devotion to God and have a positive influence on others. However, score differences for these two categories are minimal, so it is necessary to examine the smaller-than-expected difference through the qualitative analysis. Clearly, the practice average score for Group 1 was far greater than that for Group 2 because Group 1 consisted of high-active members.

\section{EMOTIONAL WELL-BEING (QUALITATIVE)}

Research has showed that Korean Protestant church affiliation is positively associated to mental well-being for female Korean immigrants in general and for male Korean immigrants who hold a staff position (minister, elder, deacon, and exhorter). ${ }^{27}$ That study, however, was restricted to Korean adult family members, and those official staff positions are not available for young adults. Thus, it is worth finding out whether this association also applies to young adults. To find an answer our research question-whether a high level of participation in church activities is related to emotional well-being as well as improving performance at the workplace/school outside the church-participants answered a number of questions. The interview responses in this respect were interesting and even counterintuitive. Only four (4/22) of the participants answered that (for them) there was a positive relationship between time devotion to church and improvement of emotional well-being. All others $(82 \%, 18 / 22)$ had negative or mixed feelings about the association between time dedication to church and improvement of emotional well-being. For example:

\footnotetext{
“No, it's not. I think it is more important to having a good mental attitude than spending time at church. So then, it would be great if I feel 'I'm happy' after serving church for [only] 1 hour, but it is not right I am forced to serve church for 8 hours.... So it is about quality than time dedication.” (Participant \#15).
} 
“No, ah no, no no. Ah, I don't like it. Emotional wellbeing could be worse. . . . Church is not only about praying for God-if it is, yes, but also about serving God with other people. Either at church and workplace, since there aren't always good things about interacting with people, ah, I don't think so. [We] could get [more] tired when spending more time [at church]. Haha." (Participant \#16).

Interview responses like the above suggest that there are stressors associated with intense church participation that may actually reduce positive emotional well-being outcomes. Young adults at Korean Presbyterian churches are highly encouraged to have positive thinking about the future because they believe God controls everything all the time, so their fates lie in God's hands as well. Thus, positive thinking was assumed to be strongly related to improved emotional well-being, so we asked them if they are worried or excited about their future. Regarding their futures, none of them expressed worry alone; more than half the participants $(55 \%, 12 / 22)$ were excited and not worried, and $32 \%$ of the participants $(7 / 22)$ were both excited and worried. The remaining three felt neither excited nor worried because they would want to leave everything to God, and one of them said "God helps those who help themselves (Participant \#8)." Those who were excited about their future had more specific expectations from God:

"Whenever I pray for my vision, help with studying, and
my life, God gives me hope. . . . Whenever I pray that
I'm not good at it and I want to give up, God keeps
giving me assurance and hope, [and He tells me,] 'Al-
though you think about yourself that way, I can make
a marvelous thing if I'm with you and I will do great
things through you.' So whenever I'm praying and
thinking about how God will use me in the future, my
heart is fluttering. I look forward to it." (Participant \#6).

Although the happiness scale was already used as a proxy measure in the screening questionnaire, participants were asked to the question "Are you mentally and physically healthy now? If so, why?" during the interview as a direct measure. Seven participants (7/22) answered that both were good. The other seven (7/22) answered that one was good but the other was moderate or bad, other seven (7/22) answered that both were bad, and the remaining one $(1 / 22)$ answered both were bad. This was consistent with earlier interview responses indicating that the connection between emotional well-being and church involvement was not found to be necessarily positive. Many participants appeared to be living diligent lives and trying to manage their time to work or study and simultaneously live a religious life. This kind of effort and striving (i.e., strain) might contribute to a belief that they are not in good mental or physical condition. However, everyone unanimously agreed that their belief in God would improve their mental and physical health:

"Yes, because when I believe in God, I become very happy, and I smile a lot. It's a happy smile-when I'm blessed with God's grace, I visibly blossom because I'm so happy." (Participant \#3).

Participants attended a Korean Presbyterian church in- stead of an American church to avoid the problem of the language barrier, enjoy cultural familiarity, pursue comfort and fellowship and share warm affection with people who have the same ethnic roots, have an opportunity to serve God, make Korean friends, or find Korean future spouses. Thus, a key purpose of attachment to the Korean Presbyterian church was that it provided a strong community spirit, so participants felt a great sense of belonging and thought "This is my community and this is my church" (Participant 13). Marrying Korean Christians was also seen as enhancing psychological stability for participants: the results of the screening questionnaire indicated that $86 \%$ (19/22) preferred or accepted only Korean people when choosing a boyfriend or girlfriend as a potential member of their family in the future, $86 \%(19 / 22)$ preferred or accepted only Korean people when choosing a partner for marriage, and 86\% (19/ 22) accepted only Christians (the other three preferred Christians) when choosing a partner for marriage. Not surprisingly, the Korean American Christian church highly encourages its members to marry Christians. ${ }^{26}$ Other motivations connected to this preference are reported in the literature. For example, working-class, Korean American, evangelical women have expressed a desire to use Christianity as a way to spiritually transform their husbands into more responsible, committed family men. ${ }^{28}$ In the in-depth interviews, all respondents revealed that they wanted to find a future spouse at church, either from their home church or other churches. In contrast to this expressed desire, however, $77 \%(17 / 22)$ said that they had not prayed for their future spouse seriously or for a long time because other prayer requests typically predominated, and they wanted to leave this matter to God. One participant even stated that she prayed for herself, not for a future spouse:
“I don't pray for my future spouse. I pray for myself. I think God already selected my perfect spouse at the beginning of the world. Because we didn't pray for our parents. We didn't pray, 'God, give me this type of par- ent.' It's given by Him, right? Just like God already se- lected our parents, God already selected my spouse when He made me. Thus, I don't have to pray for my spouse anymore. God made a perfect person because He knows me very well. The problem is me. Even if $\mathrm{He}$ sends a very good person to me, I may meet him late or meet him when I have no capacity to accept him. I pray for myself to become a wise wife and wise mom. And I pray that I would like to be obedient to that person [(my husband)].” (Participant \#3).

Importantly, not all respondents liked every aspect of the Korean church. Although currently attending Korean church, 23\% (5/22) did not mind attending either a Korean or American church. One participant pointed out that Korean churches (while Christian) are also rooted in Confucianism and are too conservative, requiring, for example, an obligatory written pledge about not drinking alcohol, or not travelling or dating with the same small group church members. Confucianism has been seen as a justification for the contemporary patriarchal structure and inequality between the gender and age groups among Korean Christians, ${ }^{29,30}$ though Koreans' belief in God challenges the Confucianinfluenced, hierarchical structure of the church's authority. ${ }^{26}$ Yet, even though this particular respondent preferred 
an American church because of these restrictions, he began attending Korean church mainly because he missed Korean people:

\begin{abstract}
“Korean people-I'd only been attending American church and only been working, then I began missing Korean people so much. It doesn't mean I like Korean church better. I still think American church is better than Korean church. [American church] is more open [and flexible] and gives more help. I'm not much of a fan of Korean church because Confucianism has been too much grained into it. But still, there are Korean people there.” (Participant \#8).
\end{abstract}

\section{WORK (OR SCHOOL) PERFORMANCE FOR GROUP 1 (QUALITATIVE)}

Work (or school) performance was considered as a single variable for participants' main business in life; most of them were workers, while some of them were students. To answer all research questions further, participants in Group 1 answered specific questions about their leadership experiences at $\mathrm{K}$ church and performance at their workplaces (schools). These particular questions were only asked of Group 1 members because they were the group that had leadership roles (There was one exception for participant \#6 from Group 2, who actively used to serve church as a leader in the past, in order to ask about the change of religious lifestyle between the past and the present). First, participants were asked about the most dedicated, enthusiastic moment among their church leadership experiences to see how they balanced their daily life between work (or school) performance and church involvement at that time. Two (2/12) answered that moment is "right now." To measure their most dedicated moments as a proxy, participants were asked the maximum number of church visits and maximum hours of church work per week they ever had. These varied depending on the kinds of leadership positions the participants held. Here are two examples:

\footnotetext{
"These days, the average time I go to bed is $2-3$ a.m. I sometimes work on [the preparation of Bible study] by 3 a.m. [Normally,] I begin at 8-9 p.m. and keep working until 2 a.m." (Participant \#5).

"I think it [(most dedicated moment)] was during the first half of last year. ... When I prepared street missions and missionary work, . . . during March and July . .. I went to church 4-5 times per week. . . . . But I can't do it just like that anymore. To be honest, I was able to do that because I was unemployed at that time." (Participant \#14)
}

Significant amounts of physical time and mental energy-the most dedicated time commitment for church that each of them was capable of-were used during their most dedicated period of time (moment); however, only three (3/ 12) said they would like to return to that moment. Many participants implied they would want to devote to the current moment the maximum passion they had for church, rather than spending the same maximum amount of physical church activities. All participants in Group 1 seemed to learn various lessons-about their personality, time management, or relationship with God-from their maximum dedication for church:

"If I did it [(church work)] again [just like that moment], I would rather spend more time for myself. . . . I would desire to live a balanced life. . . . [At that moment,] I was only at church and did church work too hard. . . I have personality that I'm not satisfied with other's work. [Because of my personality,] there were many things that I started over or did it alone. . . . If I served the same duty [just like that moment], I would be better at distributing roles to others." (Participant \#12).

"Rather than going back to that moment [(most enthusiastic moment)], I will just try to know more [about God] every day? I can't always be like that [(most enthusiastic moment)]. And I gather that, and I think I have to try to be closer [to God] every day." (Participant \#16).

Group 1 participants self-evaluated the level of satisfaction for their performance at workplaces (or schools). Eight $(8 / 12)$ were satisfied, two $(2 / 12)$ were moderate, and the remaining two $(2 / 12)$ were unsatisfied. Peer evaluation from church members and co-workers for participants could have provided objective assessment, but that was not the purpose of this study. Regardless of their actual performance, it was focused on how participants emotionally think about their life in which work and church leadership coexist. Participants were asked about the level of satisfaction for their performance and time management with regard to both working and church activities. Only four participants (4/12) provided positive answers, either doing great for both, or working on it. All others $(67 \%, 8 / 12)$ mentioned that church activities at least slightly impact on their work, especially complaining of physical fatigue:

"Well, because I'm fatigued physically [due to church activities], it may negatively affect [on my work]." (Participant \#11).

"I'm tired on Mondays. I was sick last Monday, so I couldn't go to work. Since I serve church all day long, for 9 hours without even resting on Sundays, my body breaks down and it interrupts my work.” (Participant \#16).

This is highly consistent with previous responses describing the strains and stressors associated with high levels of church involvement. Yet, although many participants suffer from time management problems between work (or study) and church activities, everyone (12/12) strongly agreed that high-level religiosity and responsibility as a church leader are a good motivation to work (or study) hard outside of the church. Two participants who even felt that their work was tedious (due to more than 10 years of working in the same area) highlighted their devotion to church as giving them mental strength and as a way to maintain motivation at the work that was given by God:

"I'm more mentally alert when I get busier [at workplace]. I get tense [positively] if there is a lot of church work as well as many personal lives [at the same time]." (Participant \#3).

"I do the best because basically, this job is provided by God. This thought and my work ethics come from my 
religiosity. All of my co-workers know that I'm a Christian. So, as a Christian, I have a mind that I would like to be a good model to them. Thus, I'm trying to work harder." (Participant \#13).

Then Group 1 participants were asked what they would have done if they had not devoted themselves to leadership positions at K church. Would the opportunity cost be high? Almost all of them (11/12) responded that they would have spent more time on non-church activities, such as hanging out with friends, dating, being with family, volunteering at organizations, travelling, enjoying oneself to the fullest, eating, resting, sleeping, watching useless stuff, shopping, or doing professional development. It appeared that they were ultimately pleased to spend valuable time by serving church as church leaders because they believed these nonchurch activities would never be more precious than their responsibilities at church. The remaining one participant felt the lack of getting closer to God because she had to spend too much time to dealing with administrative work and showing responsibility as a church leader:

“Then I would've rather focused more on worshiping, praying, and developing relationship with God because there are many administrative works as serving church. I [also] have responsibility to be the first to come and be the last to leave [church] and do something when no one does. . . . My time is limited to have one-to-one, alive relationship with God.” (Participant \#11).

Did participants think it is still good to be church leaders even if it negatively affects their work (or school) performance? In the same vein, everyone in Group 1 unanimously said "Yes" without any hesitation. Why do participants sacrifice a great deal of time on church activities? Can they focus more on their work or studies to become more competitive at the workplace or at school? Here is one answer to this question:

\begin{abstract}
"If I hadn't served the church, [my grades] could've been better than they are. But when I think of the past [when I only concentrated on studying], spiritually, I wasn't very happy. ... . Spiritually, I wasn't fulfilled. Although I've barely been passing [my classes], it is important to live a religious life for emotional well-being, spiritual health, and a long-term career." (Participant \#6).
\end{abstract}

\section{WORK (OR SCHOOL) PERFORMANCE FOR GROUP 2 (QUALITATIVE)}

Participants in Group 2 answered specific questions about their attitude toward church and performance at the workplace (or school). They were asked if there was a time conflict that prevented them from attending church every Sunday. The original expectation was that the participants in Group 2 were very busy, but this was not the case. All Group 2 participants said that they avoided the time conflict by rescheduling their work plans, finishing work faster, or finishing school classes:

"Ah-there was a lot of time conflict, but not now. I couldn't go to church because of work. I had to follow wherever my boss went, and work was also hard. There's no situation like that anymore. If I don't want to work, I don't have to work, and if I want to take a break, I can take a break [on Sundays].” (Participant \#7).

Along these lines, it was assumed going in to the study that one of the main reasons that Group 2 participants were not in leadership positions at $\mathrm{K}$ church was that they were occupied with their work (or study). They were asked what they would do if there were 48 hours in a day. Surprisingly, no one clearly answered that they would want to get more involved in church activities. It appeared that they had never imagined about doubled-hours in a day. Almost all of them said that they would want to meet more friends to overcome loneliness, do some meaningful things, focus more on work, or do volunteer work. One participant shared an interesting thought on this point:
“48 hours a day? I don't think people can't do church work well just because of time conflicts. It is just an ex- cuse. Even though there's no time, people date some- one when their eyes are sparkling [(a euphemism for being in love)]. I think it would be problem even if we were given too much time. Twenty-four hours are enough for me. God has designed [a day] as follows: 8 hours for sleeping, 8 hours for working, and 8 hours for playing." (Participant \#4).

Like Group 1 participants, Group 2 participants also selfevaluated their performance at their workplaces (or schools). Because they did not have leadership roles at $\mathrm{K}$ church and had enough time to concentrate on their work (or studies), it was expected that the performance at their workplaces (or schools) would be better than Group 1's was. The majority of them $(8 / 10)$ did say they were satisfied with their work (or school) performance, but interestingly, they did not want to work more than necessary:

"I'm doing well. But I'm not trying to do it better. . . . [This job is] not right for me.” (Participant \#18).

“I think I'm doing well responsibly. [But] whatever I'm given, I'm not all over the board. Let's say that I'm given $1,2,3$. Then, I don't do $1,2,3,4,5$. But instead, my personality is to precisely finish $1,2,3$ that are requested." (Participant \#22).

These responses were consistent with their reasons for not becoming more involved in church activities. How are participants feeling about focusing more on their work than on church? It was expected that they felt the burden of not being able to participate in church activities. However, none of them felt guilty about that and, rather, they were satisfied with their current lives.

“Guiltiness... I feel no guilty about having less time in-
side of the church, but I feel guilty about having no per-
sonal, individual time with God.” (Participant \#21).

During interviews, one of the common reasons why Group 2 participants did not join a leadership role at church was unexpected: it was due to their relatively older ages. They felt the burden and difficulty in assimilating into the mainstream of the young adult group.

"Ugh... it is about the age... to be honest, I think the core of young adult group are 20s. If it were 10-15 years ago, I would've been more involved in [church activi- 
ties]. In fact, as a senior, I don't feel like to be proactive. I think it is Korean custom." (Participant \#17).

“To be honest, now I'm old, so I think younger people should do [church activities]. Because I have no [more] enough time to be in the [young adult] group, and I feel like stepping back.... Because younger people will stay in the [young adult] group longer [than me]." (Participant \#19).

As immigrants, Group 2 participants had faced struggles to obtain permanent residency and did not have enough time or mental energy to look for Jesus or dedicate significant amounts of time serving the church and others:

\begin{abstract}
"I feel neither guilty nor comfortable. I've gone through an ordeal as an immigrant in the U.S. Someone says people find Jesus when they have trouble. I couldn't even look for Jesus when my life was so tough. ... I'd only exercised [(actual physical exercise)] in South Korea and came here through exercise. I learned a language for the first time, went through some very hard steps, and earned $\$ 600$ in the first month, and now I'm here. I really appreciate [the present and God] that I can work and earn money for what I've worked to achieve as an immigrant.” (Participant \#7).
\end{abstract}

\section{DISCUSSION}

\section{SMALL SAMPLE SIZE FROM ONE CHURCH}

It was not likely that the non-random sample size of total participants for analysis, 22, was enough to reach data saturation for each of the two groups. In addition, collecting these data drawn from only one church may not produce a generalizable conclusion. However, given the fact that this topic has been understudied, insights generated from this pilot data will help guide future studies and methodology development. A larger study to further test multiple research questions with many variables in the interview would merit consideration.

\section{EXCLUSION OF SENSITIVE QUESTIONS}

A challenge this study faced was maintaining research ethics and responsibility. Because the recruitment of participants was limited to a single church, there was a relatively high risk of a breach of confidentiality. Participants were supposed to be asked about their histories of emotional well-being or undesirable habits in greater detail and obtain honest opinions about K church. Such detailed questions about participants' lifestyle habits and experiences could bear negatively on them and potentially affect their reputations or employability. Thus, the following sensitive questions about private and personal experiences during the IRB process were excluded: 1. Did you suffer from psychological and emotional problems, such as depression? If so, have you ever talked with a psychiatrist and received psychotherapy? How did you overcome the problem? 2. Do you regret being a leader at $K$ church? 3. Do you still have a bad habit that is not sanctioned by Protestantism, such as drinking, smoking, gambling, or any other trivial thing?

Although only attenuated questions regarding emotional well-being or bad habits were allowed, it was still possible to identify linkages between strong religious beliefs and improvement of emotional well-being or avoidance of bad habits.

\section{POTENTIAL BIAS}

Another challenging situation regarding bias was that the recruitment process was shaped in part by the lead author's intuition as to whether a potential participant was a strong believer. To offset that bias, a structured Likert scale instrument was used. However, it was not easy to measure levels of belief objectively; even if screening questionnaire and in-depth interview questions were designed to gauge participants' present states, some of them may have been too modest or humble or thought they had a long way to go before becoming strong believers. Assigning the selected participants to one of the two groups was also challenging. All of them were in unique situations in their religious lives, so it was difficult to treat them with a dichotomous classification such as "high-active believer" and "inactive believer." Because most of the participants had already joined or served on a team at $\mathrm{K}$ church, it was an ambiguous distinction to assign some participants to Group 2 just because they were not currently in leadership positions.

\section{CONCLUSIONS}

Both Group 1 and Group 2 contained strong believers, and the screening questionnaire proved that the level of belief, nine fruits of Spirit, and happiness were not much different between Group 1 and Group 2. Since Group 1 consists of high-active members, the level of practice in Group 1 was much higher than that in Group 2. Group 1 had adjusted successfully to the American culture as a 1.5 or second generation because they obtained U.S. citizenship and lived a steady life with their family, whereas Group 2 had no common characteristics of legal status and living arrangement. While Group 2 had mostly been focusing on their livelihood, Group 1 had additionally been serving church and others. Group 1 participants liked to express their strong religious beliefs by dedicating themselves to church work through their leadership roles, even if this negatively affected their work (or school) performance. Some of them did not mind going to bed late to put their calling into action and carrying out their responsibility as church leaders to the full extent of their capability. However, it is a preliminary but important finding that the majority of Group 1 had negative or mixed feelings about the improvement of emotional wellbeing through church activities. Nonetheless, all of them thought it was good to be a church leader because having a strong religious belief motivated them to exert positive influence on people around them at workplace. Meanwhile, Group 2 participants did not feel the necessity of doing church work to prove their religiosity because they believed they could worship God anywhere, anytime in their daily lives. Almost all of them were satisfied with their current life and still preferred leisure time.

There was no guarantee that time dedication for church would improve Group 1's work (or school) performance because they were suffering from a time conflict between work and church activities and could not focus their energy on 
one thing. However, there was no doubt that their strong belief was a prime motivation to work or study harder as well as the main factor in developing their emotional wellbeing-though in fact many reported a negative association between intense church involvement and at least some aspects of emotional well-being.

Marrying a Korean Christian was a very important goal for participants to maintain religious belief and emotional well-being in the near future, so attending Korean church offered a potential benefit with respect to finding a partner. In addition, having a positive attitude and reason for working or studying always came from their strong spiritual beliefs, which were directly linked with their strong emotional well-being.

Three findings are particularly important, though preliminary. One is that intense involvement in church activities in itself is not necessarily linked to positive emotional well-being. In fact, for the majority of those participants reporting intense activity, it is a source of strain and stress with a negative impact on work (or school) performance. Second, for those participants who were not very involved in church activities yet reported a high level of belief, the reasons for lack of participation were generally not related to lack of time due to work or study, but to personal choice based on a view that sustaining their level of belief did not require substantial church participation, and that they preferred to spend that extra time on leisure, social activities, and meeting people. In addition, age was a sensitive issue for those who were relatively older in Group 2, leading them to feel reluctant to join a leadership role at church. Third, a consistent factor across Groups 1 and 2 was that level of belief appeared to be more important in relation to positive emotional well-being and work (or school) performance than participation. Group 3, consisting of the sole low-level believer, was screened and excluded in the data analysis because all participants should be strong believers.

This study can serve as a guide to further research on specific factors potentially associated with emotional wellbeing and social adjustment for Koreans, as well as other immigrants. Specifically, insights from this study shed light on potential elements of religious belief and practice that are related to emotional well-being and work (or school) outcomes, and on the range of reasons that individuals participate in church. As noted earlier, there may be some linkages between the demographics of Group 1 and Group 2 participants that influence level of participation in church activities, but there are not enough data from this study to support any conclusions on that issue.

\section{ACKNOWLEDGMENTS}

The authors would like to thank all participants who were willing to share their feelings and thoughts about this topic.

\section{FUNDING}

None

\section{AUTHORSHIP CONTRIBUTIONS}

CP designed the study, conducted and analyzed in-depth interviews, and wrote an initial draft. ME further developed the study design and methodology and completed a manuscript.

\section{COMPETING INTERESTS}

The authors completed the Unified Competing Interest form at www.icmje.org/coi_disclosure.pdf (available upon request from the corresponding author), and declare no conflicts of interest.

\section{CORRESPONDENCE TO}

Chulwoo Park, DrPH, MSPH

Department of Public Health and Recreation

San José State University

San José, California, United States

charles.park@sjsu.edu

Submitted: September 07, 2020 GMT, Accepted: October 05, 2020 GMT 


\section{REFERENCES}

1. Hurh WM, Kim KC. Adhesive sociocultural adaptation of Korean immigrants in the U.S.: an alternative strategy of minority adaptation. International Migration Review. 1984;18(2):188-216.

2. Park J, Roh S. Daily spiritual experiences, social support, and depression among elderly Korean immigrants. Aging and Mental Health. 2013;17(1):102-108. doi:10.1080/13607863.2012.7151 38

3. Pew Research Center. The Rise of Asian Americans. @ pewresearch. http://www.pewsocialtrends.org/201 2/06/19/the-rise-of-asian-americans/. Published 2012.

4. International Trade Administration. Top Markets Report Education Country Case Study: South Korea.; 2016. https://www.trade.gov/topmarkets/pdf/Educati on_South_Korea.pdf.

5. Lee J-S, Koeske GF, Sales E. Social support buffering of acculturative stress: a study of mental health symptoms among Korean international students. International Journal of Intercultural Relations. 2004;28(5):399-414. doi:10.1016/j.ijintrel.2 $\underline{004.08 .005}$

6. Cadge W, Ecklund EH. Immigration and Religion. Annual Review of Sociology. 2007;33(1):359-379. do i:10.1146/annurev.soc.33.040406.131707

7. Kim RY. Religion and ethnicity: Theoretical connections. Religions. 2011;2(3):312-329.

8. Pae KC. Negotiated or negotiating spaces; Korean churches in Flushing, Queens of New York City. Cross currents. 2008;58(3):456-475.

9. Pae K-JC, Ammerman NT, Cimino R, Mian NA, Weishan H. Korean American Churches and the Negotiation of Space in Flushing, Queens. In: Cimino R, Mian NA, Weishan H, eds. Ecologies of Faith in New York City. The Evolution of Religious Institutions. Bloomington, IN: Indiana University Press; 2013:81-102.

10. Chai KJ, Warner RS, Witnner JG. Competing for the Second Generation: English-Language Ministry at a Korean Protestant Church. In: Warner RS, Witnner JG, eds. Gatherings In Diaspora: Religious Communities and the New Immigration. Religious Communities and the New Immigration. Philadelphia, PA: Temple University Press; 1998:295-332.
11. Roh S. The impact of religion, spirituality, and social support on depression and life satisfaction among Korean immigrant older adults. New York University doctoral dissertation. 2010.

12. Heo GJ, Koeske GF. Religious Involvement and Depression Among Korean Young Adults in the United States. Journal of Religion \& Spirituality in Social Work: Social Thought. 2010;29(2):91-108. doi:1 $\underline{0.1080 / 15426431003708170}$

13. Koenig HG, Idler E, Kasl S, et al. Religion, spirituality, and medicine: a rebuttal to skeptics. Int J Psychiatry Med. 1999;29(2):123-131. doi:10.2190/c2f b-95vw-fkyd-c8rv

14. Koenig HG. Religion, spirituality, and health: the research and clinical implications. ISRN Psychiatry. 2012:278730. doi:10.5402/2012/278730

15. Chang SI. Developing an Embedded Process of Spiritual Healing/Growth for South Korean Presbyterian Churches. 2015.

16. Schutte NS, Malouff JM, Simunek M, McKenley J, Hollander S. Characteristic emotional intelligence and emotional well-being. Cognition and Emotion. 2002;16(6):769-785. doi:10.1080/02699930143000482

17. Watson D, Clark LA. Emotions, moods, traits, and temperaments: Conceptual distinctions and empirical findings. The nature of emotion: Fundamental questions. 1994:89-93.

18. Watson D, Clark LA, Tellegen A. Development and validation of brief measures of positive and negative affect: the PANAS scales. Journal of personality and social psychology. 1988;54(6):1063.

19. Watson D, Wiese D, Vaidya J, Tellegen A. The two general activation systems of affect: Structural findings, evolutionary considerations, and psychobiological evidence. Journal of personality and social psychology. 1999;76(5):820.

20. Bednar RL, Peterson SR. Self-Esteem: Paradoxes and Innovations in Clinical Theory and Practice. American Psychological Association; 1995.

21. Mruk CJ. Defining Self-Esteem: An Often Overlooked Issue with Crucial Implications. 2006.

22. Mruk CJ. Changing self-esteem: Research and practice. Self-esteem issues and answers: A sourcebook of current perspectives. 2006:164-169. 
23. Mruk CJ. Self-Esteem and Positive Psychology: Research, Theory, and Practice. Springer Publishing Company; 2013.

24. Hills P, Argyle M. The Oxford Happiness Questionnaire: a compact scale for the measurement of psychological well-being. Personality and individual differences. 2002;33(7):1073-1082.

25. Kim AE. Characteristics of Religious Life in South Korea: A Sociological Survey. Review of Religious Research. 2002;43(4):291-310. doi:10.2307/3512000

26. Park K. “Born again”: what does it mean to Korean-Americans in New York City? Journal of Ritual Studies. 1989;3(2):287-301.

27. Hurh WM, Kim KC. Religious participation of Korean immigrants in the United States. Journal for the Scientific Study of Religion. 1990;29(1):19-34.
28. Kim S. Working-class, Korean-American women navigating marriage through evangelical Christianity. Journal of Comparative Family Studies. 2010;41(5):735-748.

29. Chong KH. What It Means to Be Christian: The Role of Religion in the Construction of Ethnic Identity and Boundary among Second-Generation Korean Americans. Sociology of Religion. 1998;59(3):259-286. doi:10.2307/3711911

30. Kang N. Resurgence of Asian values: Confucian comeback and its embodiment in Christianity. In: Diasporic Feminist Theology. Asia and Theopolitical Imagination. Minnesota, MN: Augsburg Fortress, Publishers; 2014:291-322. 


\section{SUPPLEMENTARY MATERIALS}

\section{Online Supplementary Document}

Download: https://www.joghr.org/article/17608-the-effects-of-spiritual-experience-and-church-commitment-amongsouth-korean-young-adult-immigrants-in-the-united-states-a-mixed-methods-study/attachment/46648.pdf 